\title{
DIRECT ACTIONS AGAINST INSURERS IN CROSS-BORDER TRAFFIC ACCIDENTS IN AN EUROPEANISED PRIVATE INTERNATIONAL LAW - WHAT PROTECTION FOR THE INJURED PARTIES?
}

Summary: $\quad$ This article offers a discussion of the law applicable to cross-border traffic accidents, from the perspective of the protection of injured parties. The introduction of principles like direct actions against insurers by injured third parties (forum actoris), mostly because of CJEU's liberal approach, puts into question the relationship between European private international law and national Member State rules of conflict-of-laws. This article aims to propose an answer to the question "Does the European private international law set of rules offer an adequate protection for the injured parties?" with the view of offering also a few recommendations for the reformation of the Rome II Regulation.

Keywords: cross-border traffic accidents, forum actoris, direct action, applicable law, European private international law 


\section{INTRODUCTION}

The constant evolution of different areas of law under the blessings of globalization and Europeanisation is a process that brings about changes within national Member State (MS) concepts that are worth of an examination. Private international law (to be found throughout this article also as PIL) makes no exception in this regard. ${ }^{1}$ Evolutions in European jurisprudence on private international law and their repercussion in the European PIL have inspired this article and a line of thought that has been developed these past years in legal research ${ }^{2}$ on the Europeanisation of PIL: starting with the obligation of recognition and application of previously acquired rights for individuals and companies, with the aim of ensuring a fully functional and operational internal market within the territorial space of the European Union (EU), ${ }^{3}$ to assuring the protection of "weaker parties" in cases of claims for compensation in non-contractual liability (tort) law, the concept of defending the "vulnerable" merits a thorough examination in so far as to understand the extent of which these multiple and sometimes freshly constructed mechanisms, ${ }^{4}$ have influenced the sphere of European private international law.

In the view of globalization, people are interacting more than ever with one-another in contexts of cross-border settings, whereas developments in transport and technology are by all means facilitating this globalist approach of the modern life. Thus, for instance a French citizen that rents online an Austrian-based car, in order to spend his vacations travelling in Slovenia and probably causing an accident that involves a local resident, is a scenario that might very likely happen. Within the space of the European Union, these new developments have been crucial for the reshaping of private international law, often leading to what academics call a "new legal discipline", commonly referred as European private international law. ${ }^{5}$ Even though often it is indeed labelled as new, European private international law is quite a consolidated discipline and this article will lead into a deeper exploration of this context.

In order to continue the line of thought expressed earlier, this article aims to cast some light in a very specific concept of the way how European private international law deals with the claims for compensation in non-contractual liability cases and how it influences individual MS's private international law. Hence, the direct action against insurers mainly for traffic acci-

1 Mills, A., Rediscovering the public dimension of private international law, 30 Nederlands Internationaal Privaatrecht (NIPR), (2012), pp. 371-375.

2 See Kuipers, J. J., Cartesio and Grunkin-Paul. Mutual Recognition as a Vested Rights Theory based on Party Autonomy in Private Law, 2 European Journal of Legal Studies (2008), p. 66-96. See also Vyshka, K., Changing balances of PIL theories in a Europeanized Private International Law, Maastricht Journal of European and Comparative Law (2018), Vol. 25(5) 533-550.

3 See jurisprudence like Case C-148/02 Garcia Avello, EU:C:2003:539, Case C-353/06 Grunkin-Paul, EU:C:2008:559 and in company law, more recently Case C-106/16 Polbud, EU:C:2017:804. For more on this topic, see Vyshka, K., Changing balances of PIL theories in a Europeanized Private International Law, Maastricht Journal of European and Comparative Law (2018), Vol. 25(5) 533-550.

4 Almost exclusively by the activism of the Court of Justice, which sometimes is heavily criticized by the academia; see for instance Davies, G Does the Court of Justice own the Treaties? Interpretative pluralism as a solution to over-constitutionalization, Eur Law J. (2018); p. 358-375.

5 See Joerges, C., The Challenges of Europeanization in the Realm of Private Law: A Plea for a New Legal Discipline, Duke Journal of Comparative and International law, Vol 14:149, (2004) p. 149-196. 
dents within the territory of the EU will be discussed. With the Odenbreit ${ }^{6}$ jurisprudence, the CJEU interpreted in a novel way the possibility of undertaking a direct action against insurers, because of its interest to protect weaker parties. ${ }^{7}$ The forum actoris that the Odenbreit ${ }^{8}$ case established is also expected to bring a considerable amount of changes in litigation practices in non-contractual liability. ${ }^{9}$

The realm of cross-border traffic accidents is by no means an easy one to understand, nor an area in which the Europeanisation of conflict-of-law rules has been fully completed. ${ }^{10}$ Being a decisive area of practical importance, it does seem as the Rome II Regulation plays a great role as an influential instrument for the rules designating the applicable law. ${ }^{11}$ Thus, recital 6 of the Regulation notes that "the proper functioning of the internal market creates a need, in order to improve the predictability of the outcome litigation, certainty as to the law applicable and the free movement of judgements, for the conflict-of-law rules in the Member States to designate the same national law irrespective of the country of the court in which an action is brought."12

For a part of the academia, it would seem like Rome II Regulation "flatters itself" 13 when it says that it contributes to improve the legal certainty of European citizens and that it even "exaggerates" in this self-assessment, since it nevertheless, gives way of application also to the Hague Convention on the law applicable to traffic accidents, ${ }^{14}$ already putting an extra layer of complexion to the cross-border traffic accidents, which now are between a binome of instruments.

The most important twist that concerns this study, is that depending on which court is seized to give a ruling upon a cross-border traffic accident, the applicable law will be governed either by Rome II Regulation, or the Hague Convention. ${ }^{15}$ The scenario of "forum-shopping" does then look as very likely, since the victim has the ability to choose between different conflict regimes, leading to the application of different substantive laws. ${ }^{16}$

Therefore, the relationship between Rome II Regulation and The Hague Convention on the law applicable to traffic accidents needs to be examined and explained throughout. However, it is erroneous to believe that cross-border traffic accidents are ruled only within this binome. It

6 Case C463/06 Odenbreit, ECLI:EU:C:2007:792.

7 See Knetsch, J., "La réparation du dommage extracontractuel en droit international privé" in Le droit à l'épreuve des sciècles et des frontières, Lextenso (2018), p. 979-1018, at p. 980.

8 Case C463/06 Odenbreit, ECLI:EU:C:2007:792.

9 Knetsch, op. cit., p. 979-1018.

10 Graziano, T. The Rome II Regulation and The Hague Conventions on Traffic Accidents and Product Liability - Interaction, conflicts and future perspectives, Nederlands Internationaal Privaatrecht (NIPR) (2008), 425-429, at p. 425.

11 Idem, see also in general Van Calster, G European Private International Law, (2010) Hart Publishing.

12 Recital 6, Regulation (EC) No 864/2007 of the European Parliament and of the Council of 11 July 2007 on the law applicable to non-contractual obligations (Rome II) OJ L 199, 31. 7. 2007.

13 Nagy, C., The Rome II Regulation and Traffic Accidents: Uniform Conflict Rules with some Room for Forum Shopping - How so?, Journal of Private International Law, Vol 6, Issue 1, 2010, 93-108, at p. 93.

14 Convention on the law applicable to traffic accidents; Concluded at The Hague on 4 May 1971.

15 See in general Graziano, op. cit., pp. 425-429.

16 Nagy, op. cit., p. 94. 
seems more of a tripartite relationship when we realize that instruments like the Motor Insurance Directives ${ }^{17}$ also apply. It becomes even more interesting on the point of view of the victim, since the MIDs are de facto a "social policy seeking to minimize the impact, on victims, of the large volumes of loss and injury that occur in the EU as a result of road traffic accidents." 18

Therefore, in a nutshell this article aims to explore how the European private international law rules of non-contractual obligations protect the victims and injured parties in cases of cross-border traffic accidents and by identifying the disadvantages in the system, to ascertain if a "modernization" of Rome II Regulation is needed. In principle, this article will indeed find that certain aspects of Rome II are unsatisfactory as regards providing a full protection for the injured parties (its co-existence with The Hague Convention and the exclusion of issue-by-issue analysis, or else known as dépeçage above all), but will also confirm that the CJEU jurisprudence in matters of direct actions against insurers are a good step forward.

All in all, our premise is that EU law influences the methods of private international law and this article reinforces the general picture of the influence of European private international law upon traditional private international laws in individual Member States (MS), through the application of the forum actoris, or the possibility of the injured party to bring a direct action against the insurer before the courts of his/her country of residence.

This article first assesses the position of injured parties from the law applicable to cross-border traffic accidents, namely the general rules of Rome II Regulation in section 2. An analysis following Article 4 of Rome II is carried out in this section, highlighting especially the consequences for injured parties of the exclusion of the so-called dépeçage principle. Section 3 then explores the inconveniences in this regard that this policy choice of excluding the application of dépeçage has for the protection of injured parties, analyzing as well the case law of CJEU on determining a right of direct action against insurers for injured parties. A fourth section concludes and invites for a re-shaping of the policies within Rome II, especially centered to cross-border traffic accidents.

\section{THE LAW APPLICABLE TO CROSS-BORDER TRAFFIC ACCIDENTS - A REFLECTION ACCORDING TO THE VICTIM'S POINT OF VIEW}

Since 11 January 2009, ${ }^{19}$ the Rome II Regulation has established a unification of the the non-contractual obligations area of European PIL. As such, the Rome II Regulation ${ }^{20}$ puts in place a number of unified rules which have direct effect as regards conflict-of-laws for a specific part of the private international law. The practical significance of these rules in national

17 Council Directives 72/166/EEC [1972] OJ L103\ 84/5/EEC [1984] OJ L8/17) 90/232/EEC [1990] OJ L129/33; 2000/26/EC [2000] OJ L181/65 and 2005/14/EC [2005] OJ L149/14, consolidated in Directive 2009/103/EC [2009] OJ L263/11.

18 Papettas, J., Direct Actions against Insurers of Intra-Community Cross-Border Traffic Accidents: Rome II and the Motor Insurance Directives, Journal of Private International Law, Vol 8, Issue 2, 2012, (2012) p. 297-321, at p. 297.

19 Articles 31-32 of Regulation (EC) No 864/2007 of the European Parliament and of the Council of 11 July 2007 on the law applicable to non-contractual obligations (Rome II) OJ L 199, 31. 7. 2007.

20 See in general Regulation (EC) No 864/2007 of the European Parliament and of the Council of 11 July 2007 on the law applicable to non-contractual obligations (Rome II) OJ L 199, 31. 7. 2007. 
Member State PIL is deemed to be high, ${ }^{21}$ especially in relation to European tort law. In cases of random and unplanned damages that include a foreign (European) element, it is logical that legal certainty is one of the core principles that would benefit the parties involved, as well as the establishment of a set of "practical connecting factors". ${ }^{22}$ Compared to contractual obligations, the non-contractual realm seems to be more complicated, as the parties autonomy of choosing the applicable law is restrained to a post facto application. ${ }^{23}$

This paper briefly discusses the general principles of Rome II Regulation, because traffic accidents, even though very practical in nature, are not included amongst the specific provisions that rule upon a given set of torts, ${ }^{24}$ such as product liability, unfair competition, environmental damage, intellectual property rights or industrial action. This means that in order to determine the applicable law in a cross-border traffic accident, the general rules of Rome II Regulation apply. ${ }^{25}$

In this context, article 4(1) establishes the general rule for the applicable law in non-contractual obligations and decides that "the law applicable to a non-contractual obligation [...] shall be the law of the country in which the damage occurs." 26 The Rome II Regulation opts therefore for the designation of the place of direct damage as a connecting factor (mostly known as lex loci damni or Erfolgsort ${ }^{27}$ ). The choice of a lex loci damni comes as well with an abandon of the previous principle of lex loci delicti commissi, ${ }^{28}$ which according to Recital 15 of the Regulation, is indeed the common solution in most of the Member States, but its application in a context of an Europeanised private international law would endanger the certainty as to the law applicable.

21 Hohloch, G., Place of Injury, Habitual Residence, Closer Connections and Substantive Scope - the Basic Principles in Yearbook of Private International Law, Vol. 9, 2007, pp. 1.-18.

22 Hohloch, op. cit., p. 2.

23 Article 14 Regulation (EC) No 864/2007 of the European Parliament and of the Council of 11 July 2007 on the law applicable to non-contractual obligations (Rome II) OJ L 199, 31. 7. 2007. See also Kadner Graziano, T., Freedom to Choose the Applicable Law in Tort - Articles 14 and 4(3) of the Rome II Regulation in Ahern, J., and Binchy, W. (eds.), The Rome II Regulation on the Law Applicable to Non-Contractual Obligations: A New International Litigation Regime, 2009 Martinus Nijhoff Publishers.

24 Articles 5-9 of Regulation (EC) No 864/2007 of the European Parliament and of the Council of 11 July 2007 on the law applicable to non-contractual obligations (Rome II) OJ L 199, 31. 7. 2007. See also Von Hein, J "Article 4 and Traffic Accidents" in Ahern, J and Binchy, W. (eds.), The Rome II Regulation on the Law Applicable to Non-Contractual Obligations: A New International Litigation Regime, (2009) Martinus Nijhoff Publishers; Brière, C "Le règlement (CE) n 864/2007 du 11 juillet 2007 sur la loi applicable aux obligations non contractuelles" (2008) 135 Clunet 31; Garcimartín Alférez, F. J “The Rome II Regulation: On the way towards a European Private International Law Code" (2007) 7 EuLF 1; Kadner Graziano, T "General Principles of Private International Law of Tort in Europe' in: Basedow et al. (ed), Japanese and European Private International Law in Comparative Perspective (2008) Tübingen, Mohr Siebeck; Stone, P., “The Rome II Regulation on Choice of Law in Tort” (2007) 4 Ankara L. Rev. 95-130; Symeonides, S "Rome II and Tort Conflicts: A Missed Opportunity" (2008) 56 Am. J. Comp. L. 173.

Von Hein, J., "Something Old and Something Borrowed, but Nothing New? Rome II and the European Choice-of-Law Evolution" (2008) 82 Tulane L. Rev 1663.

25 Article 4 and 14 Regulation (EC) No 864/2007 of the European Parliament and of the Council of 11 July 2007 on the law applicable to non-contractual obligations (Rome II) OJ L 199, 31. 7. 2007.

26 Article 4.1 Regulation (EC) No 864/2007 of the European Parliament and of the Council of 11 July 2007 on the law applicable to non-contractual obligations (Rome II) OJ L 199, 31. 7. 2007.

27 See in general Hohloch, op. cit. pp. 1-18; see also Van Calster, op. cit., and Von Hein, J., "Article 4 and Traffic Accidents" in Ahern, $\mathrm{J}$ and Binchy, W. (eds.), The Rome II Regulation on the Law Applicable to Non-Contractual Obligations: A New International Litigation Regime, 2009 Martinus Nijhoff Publishers.

28 Van Calster, op. cit., p. 252. The Rome II Regulation expressly ignores the law of the country in which the event giving rise to the damage occurs and the country where indirect damage occurs. 
As such, Rome II Regulation considers itself as the instrument that enhances the predictability of the litigation outcome ${ }^{29}$ and it specifically instructs to set aside the application of lex loci delicti commissi, as well as the law of "the country in which the indirect consequences of that event occur", ${ }^{30}$ rule similarly applied also by Brussels I, following the Marinari ${ }^{31}$ judgement. How does all this relate to a victim of a cross-border traffic accident will be explained in the next subsections.

\subsection{THE GENERAL RULE}

A clarification between different concepts, like "event giving rise to damage" versus "damage" as according to the terminology of Article 4 Rome II Regulation, and "harmful event", as referred to Article 5 Brussels I Regulation ${ }^{32}$ seems pertinent here. Article 4 of Rome II Regulation opts for a more restrictive approach to the term "event", meaning that it only refers to the "place of acting" 33 of the tort/delict, whereas in Brussels I, the term comprises both the place of acting and of injury. ${ }^{34}$ In terms of Rome II, therefore, "place of injury" refers to the place where the direct damage occurred..$^{35}$ Although the phrasing of Rome II Regulation is puzzling when it comes to the term "damage" as opposed to "injury", the subsequent clear exclusion of the indirect consequences of the event, makes the lex loci damni a generally accepted solution. ${ }^{36}$ Practically speaking, if a victim of a cross-border traffic accident that happened in the German highways, gets paralyzed as a consequence in his state of origin, say France, the Rome II Regulation stipulates that the "damage" was suffered in Germany, where "the victim's bodily integrity was harmed." 37

However, even though the Rome II Regulation does refer to a "general rule" this seems to be more or less as a subsidiary solution, given that party autonomy, as set out in Article 14 of the same Regulation, prevails. These provisions taken altogether, from a victim's perspective, the lex loci damni solution, according to Van Calster, is a connecting factor that most of the

29 See Recital 6 Regulation (EC) No 864/2007 of the European Parliament and of the Council of 11 July 2007 on the law applicable to non-contractual obligations (Rome II) OJ L 199, 31. 7. 2007.

30 Article 4 of Regulation (EC) No 864/2007 of the European Parliament and of the Council of 11 July 2007 on the law applicable to non-contractual obligations (Rome II) OJ L 199, 31. 7. 2007.

31 Case C-364/93 Antonio Marinari v Lloyds Bank et al, [1995] ECR I-2719; see also Symeonides, op. cit.

32 Council Regulation (EC) 44/2001/EC on Jurisdiction and the Recognition and Enforcement of Judgments in Civil and Commercial Matters, (2001) OJ L/12/1.

33 Von Hein, Article 4..., op. cit., p. 158.

34 See the leading case, Case 21/76 Bier v Mines de Potasse d'Alsace [1976] ECR 1735; for a discussion see Mankowski, U and Magnus P (eds), Brussels I Regulation, Second revised edition, (2012) Munich, Sellier ELP

35 For a similar wording, see also Article 5 of Council Regulation (EC) 44/2001/EC on Jurisdiction and the Recognition and Enforcement of Judgments in Civil and Commercial Matters, (2001) OJ L/12/1.

36 Garcimartín Alférez, F. J "The Rome II Regulation: On the way towards a European Private International Law Code" (2007) 7 EuLF 1; Hay, P., "Contemporary Approaches to Non-Contractual Obligations in Private International Law (Conflict of Laws) and the European Community's “Rome II” Regulation” (2007) 7 EuLF 1.

37 Von Hein, Article 4..., op. cit., p. 159 and Recital 17 of Regulation (EC) No 864/2007 of the European Parliament and of the Council of 11 July 2007 on the law applicable to non-contractual obligations (Rome II) OJ L 199, 31. 7. 2007. 
time will lead to the application of the "law of the victim," ${ }^{38}$ as opposed to the interests of the tortfeasor. In general, there is a feeling that the Rome II Regulation, its general rules, and some of the specific rules like environmental damage or product liability, favors the victim and/or the consumer, giving to this instrument an overall approach from the point of view of the sufferer. ${ }^{39}$ And indeed, this approach favors what Dickinson labels as the primary objective of tort law: the equal distribution of loss among members of society. ${ }^{40}$

Would we then be pointing out slowly towards a victim-based modernization, insofar as Recital 16 of the Rome II Regulation says that: "Uniform rules should enhance the foreseeability of court decisions and ensure a reasonable balance between the interests of the person claimed to be liable and the person who has sustained damage. A connection with the country where the direct damage occurred (lex loci damni) strikes a fair balance between the interests of the person claimed to be liable and the person sustaining the damage, and also reflects the modern approach to civil liability and the development of systems of strict liability." ${ }^{41}$ On the other hand, due to the fact that tort law and compensation for damage in Member States is far from harmonized, it could very well be the case that in cross-border traffic accidents, the state where the law of the place of injury (bodily integrity harmed) rather than the law of the place of acting (event) favors the victim by providing for higher standards of protection, or higher sums paid in compensation, therefore, the generalization that lex loci damni protects the victim should not always be taken for granted. ${ }^{42}$

To continue this line of thought and as opposed to some Member State's PIL solutions, like Italy or Germany, ${ }^{43}$ Rome II Regulation does not offer to the victim the possibility of choice between "the place of acting and the place of injury". ${ }^{44}$ This would, on the contrary, show a prevalence of the Savignian paradigm within Rome II, which not always works in favor of the victim or the vulnerable party, ${ }^{45}$ and which prefers to opt for a conflict-of-laws justice rather than choosing the application of the law most favorable to the victim. ${ }^{46}$ Again, this is a somehow relative truth, since the de facto results of traffic accidents often lead to the same place of injury and the place of acting. ${ }^{47}$

38 Van Calster, op. cit., p. 252. Although, it is unclear what the author means with "law of the victim": is it the law most favourable to the victim or the law of the country where the victim has his/her habitual residence?

Van Calster, op. cit., p. 252.

Dickinson, A., The Rome II Regulation (Oxford, OUP, 2008), at p. 7.

Recital 16 of Regulation (EC) No 864/2007 of the European Parliament and of the Council of 11 July 2007 on the law applicable to non-contractual obligations (Rome II) OJ L 199, 31. 7. 2007.

See in general Symeonides, op. cit., p. 173.

See for example Article 40(1) of the German EGBGB (Einführungsgesetz zum Bürgerlichen Gesetzbuch), for a discussion on this see Hay, P., "From Rule-Orientation to "Approach" in German Conflicts Law: The Effect of the 1986 and 1999 Codification" (1999) 47 Am. J. Comp. L. 633. For the Italian case, see Article 62 of the law of 31 may 1995, n. 218 (1): Riforma del sistema italiano di diritto internazionale private; for a discussion see Giardina, A., "Italy: Law Reforming the Italian System of Private International Law" (1996) 35 International Legal Materials, p. 760-782.

Von Hein, op. cit., p. 160.

Vyshka, op. cit., pp. 533-550.

See also Von Hein, op. cit., p. 160.

Junker, A “Das Internationale Privatrecht der Straßenverkehrsunfälle nach der Rom II-Verordnung” (2008) 63 JZ, p. 169. 
However, the Savignian roots of Rome II Regulation are clearly distinguished in the choice to uphold a unitary connection of a non-contractual obligation to only one legal order, instead of practicing the dépeçage. ${ }^{48}$ In other terms, the applicable law that determines the liability of a party is also the law that determines the evaluation of the damages caused (lex causae). ${ }^{49}$ Maybe for the sake of simplicity and harmonization, or simply because this solution was already the one that prevailed in numerous Member States' national rules ${ }^{50}$ as well as in international instruments, such as the Hague Conventions, ${ }^{51}$ the Commission preferred to submit the issues of damages quantifications to the law of the country that determines the liability (in other words, the law of the country where the damage has occurred). ${ }^{52}$

Even though following a unitary approach that would allegedly improve predictability as regards the applicable law, ${ }^{53}$ the lex causae connecting factor in damage quantification does not always protect the victim. As it has been developed elsewhere, ${ }^{54}$ the strict application of the Savignian paradigms does not favor an interpretation that would lead towards the best solution for the victim or the vulnerable party in general. This solution came after the Commission decided not to follow the European Parliament's position, which from its side had proposed a dépeçage between the applicable law for the liability and the applicable law for the damages quantification. ${ }^{55}$ Concretely, the Parliament's proposal stipulated that "in the case of personal injuries arising out of traffic accidents [...] with a view to the motor insurance directive, the court seized and the liable driver's insurance shall, for the purposes of determining the type of claim for damages and calculating the quantum of the claim, apply the rules of the individual's victim's place of habitual residence unless it would be inequitable to the victim to do so. With regard to liability, the applicable law shall be the law of the place where the accident occurred." 56

The position of the victim is as a consequence, not very clear within the Rome II Regulation. What would protect a victim, say if we take a mere example of a person with habitual residence in France who suffers damages and losses in Bulgaria, from the potential gap between these two countries' rules and actual costs of medical care in cases of traffic accidents, is only the

48 Von Hein, op. cit. p. 160; Kozyris, J., Rome II: Tort Conflicts on the Right Track! A Postscript to Symeon Symeonides' 'Missed Opportunity', Am J. Comp. L, Vol 56, 2008, p. 471; Stone, op. cit., p. 95-130.

49 See Article 15 of Regulation (EC) No 864/2007 of the European Parliament and of the Council of 11 July 2007 on the law applicable to non-contractual obligations (Rome II) OJ L 199, 31. 7. 2007, insofar as it says "The law applicable to non-contractual obligations under this Regulation shall govern in particular: c) the existence, the nature and the assessment of damage or the remedy claimed."

See Knetsch, op. cit., p. 979-1018, at p. 985. See also Kadner Graziano, T., La responsabilité délictuelle en droit international privé européen (2004), Helbing \& Lichtenhahn/Bruylant/LGDJ, at p. 105.

51 Convention on the law applicable to traffic accidents; Concluded at The Hague on 4 May 1971 and Convention of 2 October 1973 on the Law Applicable to Products Liability.

52 See in general, See Knetsch, op. cit. pp. 979-1018.

53 See Nagy, C., op. cit., pp. 93-108.

54 Vyshka, op. cit., pp. 533-550.

55 See Position of the European Parliament adopted at first reading on 6 July 2005 with a view to the adoption of Regulation (EC) No .../2005 of the European Parliament and of the Council on the law applicable to non-contractual obligations ("ROME II"); See also Malatesta, A. (ed), The Unification of Choice of Law Rules on Torts and Other Non-Contractual Obligations in Europe (2006) Padova, CEDAM, at p. 392. See also Von Hein, op. cit., p. 155.

56 Art 4.2 of Regulation (EC) No 864/2007 of the European Parliament and of the Council of 11 July 2007 on the law applicable to non-contractual obligations (Rome II) OJ L 199, 31. 7. 2007. 
recital 33 of the Regulation, ${ }^{57}$ with no binding power. One would say, like for example scholars as Symeonides, ${ }^{58}$ that Rome II does not sound unitary at all and that it even fails its mission of assuring more legal certainty in cases of non-contractual obligations and righteously so, since the recital 33 uses the phrasing "the court seized should take into account [...]." Whether this shows an immature political will to apply in the future a principle of dépeçage only to traffic accidents or simply a "political gesture" 59 that was enough to satisfy the Parliament, this remains to be seen.

As a preliminary conclusion and for the time being, I believe that the specificity of cross-border traffic accidents does require more harmonization within the European private international law, at least in the form of a specific rule within the same Regulation. In this context, the European Parliament's draft of $2005^{60}$ might be interesting to refer to, in case one's interests would be full advocacy for the victims and the vulnerable parties' rights.

\subsection{THE GENERAL EXCEPTION TO THE GENERAL RULE AND THE ESCAPE CLAUSE}

Following the general rule of Rome II Regulation, is the general exception which favors the application of the law of the country where both parties "have their habitual residence." 61 Being a notion that is familiar to many national conflict-of-laws rules, ${ }^{62}$ the common habitual residence represents the basic effectiveness rationale of the Regulation: in most cases the common habitual residence means also lower financial costs for the judicial proceedings, or even familiarity with the proceedings, since the judicial system of the place of residence is usually best known to the parties. ${ }^{63}$

Nevertheless, the common habitual residence remains an exception to the general rule, again in contrary to the views of the European Parliament's draft proposal. ${ }^{64}$ Always in favor of a dépeçage between the applicable law determining the liability and the one determining the quantification of damages, the European Parliament's proposed solution of applying the

57 Recital 33 of Regulation (EC) No 864/2007 of the European Parliament and of the Council of 11 July 2007 on the law applicable to non-contractual obligations (Rome II) OJ L 199, 31. 7. 2007 reads: "According to the current national rules on compensation awarded to victims of road traffic accidents, when quantifying damages for personal injury in cases in which the accident takes place in a State other than that of the habitual residence of the victim, the court seized should take into account all the relevant actual circumstances of the specific victim, including in particular the actual losses and costs of after-care and medical attention."

58 Symeonides, op. cit., p. 183.

59 See Knetsch, op. cit., p. 987.

60 Position of the European Parliament adopted at first reading on 6 July 2005 with a view to the adoption of Regulation (EC) No .../2005 of the European Parliament and of the Council on the law applicable to non-contractual obligations ("ROME II").

61 Art 4.2 of Regulation (EC) No 864/2007 of the European Parliament and of the Council of 11 July 2007 on the law applicable to non-contractual obligations (Rome II) OJ L 199, 31. 7. 2007.

62 Kadner Graziano, T., Gemeineuropäisches Internationales Privatrecht, 2002, Tübingen, Mohr Siebeck, at p. 379-388. See also Hohloch, op. cit., pp. 1-18.

63 Dornis, T. W., 'When in Rome, do as the Romans do?' - A Defense of the Lex Domicilii Communis in the Rome II-Regulation, Eulf, Issue 4, 2007, I-152, I-157.

64 Position of the European Parliament adopted at first reading on 6 July 2005 with a view to the adoption of Regulation (EC) No .../2005 of the European Parliament and of the Council on the law applicable to non-contractual obligations ("ROME II"). 
law of the victim's habitual residence in the quantification of damages, was not deemed as proportional. Even though the interests of the victim need to be protected, the general view ${ }^{65}$ was that such a dépeçage would "endanger the tortfeasor's legitimate interest in foreseeability of the applicable law." 66

And indeed, if we continue the pathway of this scenario, there is also another issue at stake, and that is finding the balance between the interests of the victim and the tortfeasor on the other side. As such, the tortfeasor could also be held liable and made to pay damages to a victim according to the law of a country which he/she could not have anticipated. Should we choose to base the applicable law on the habitual residence of the victim, an Italian driver for example, that causes injuries to a Slovenian tourist due to a traffic accident in Spain, would be held liable according to the Slovenian laws of the damage quantification. ${ }^{67}$

On the other hand, the possibility of this choice not being always favorable to the victim exists, if we were to believe that the amount of damage compensation according to the laws of Slovenia is less favorable to the victim than what the Spanish laws would have granted to him/her. ${ }^{68}$ In such cases, the Parliament would empower the courts dealing with the specific case to instead apply the law most favorable to the victim. ${ }^{69}$ As Von Hein righteously pointed out, this would have created a "mix of considerations," ${ }^{70}$ which alongside the fact that it would undermine the legal certainty principle that Rome II Regulation vows to install, it would also have introduced a combination of connecting factors exclusively in favor of the victim. ${ }^{71}$

Yet again, striking the right balance between the victim and the tortfeasor interests comes into play. It is nevertheless undeniable that Rome II Regulation has chosen not to follow the so-called Ubiquity theory, rule that has been in place, for example, in Germany since $1999^{72}$ and that is based in the principle of applying the law most favorable to the victim, giving the freedom of choice between the law of the place of acting and the place of injury, in cases where they do not coincide. ${ }^{73}$ Rome II Regulation seems as such more prone to following the Savignian principles of "conflicts justice" rather than "substantive justice". ${ }^{74}$

The establishment of a right balance could be and is beyond doubt difficult, but these general observations up until now invite at least to conduct a reflection of what a future and

65 For a criticism see Malatesta, op. cit. pp. 96-99; Adensamer, M., "Der Verkehrsunfall im Licht der Rom-II-Verordnung”, (2006) 51 ZVR 523; Staudinger, A., Rome II and traffic accidents, Eulf, Issue 5, 2005, 1-61. Alternatively, for a positive view on this see Bona, M., Personal Injuries, Fatal Accidents and Rome II: Can the Law of the Country where the Victim Suffers Provide Full and Fair Compensation? in Malatesta, op. cit.

Von Hein, op. cit., p. 161; see also Malatesta, op. cit., p. 98; Adensamer, op. cit.

67 For other similar examples, see Von Hein, op. cit., p. 161.

68 Adensamer, op. cit.

69 See in general Position of the European Parliament adopted at first reading on 6 July 2005 with a view to the adoption of Regulation (EC) No .../2005 of the European Parliament and of the Council on the law applicable to non-contractual obligations ("ROME II"), especially the proposed Article 7.

Von Hein, op. cit., p. 162.

oin, Article 4..., op. cit., p. 162; see also Malatesta, op. cit., p. 98

See Hohloch, op. cit. pp. 1-18, at p. 8 and Article 40.1 of the German EGBGB. (2003) 427 final 2003/0168 (COD). 
"upgraded" Rome II could look like. For the time being, the victim can only rely, as mentioned before, to the Recital 33, of the Regulation, which merely instructs the competent court to take into account the actual losses suffered from the injured party. ${ }^{75}$ Whether this solution from the side of the European legislator is ultimately put into question by the Court of Justice of the EU (CJEU), with its Odenbreit ${ }^{76}$ jurisprudence, this will be the question that we will try to answer in the second section of this paper, alongside a discussion for the reformation of Rome II Regulation.

To continue the purposes of this section, Article 4 of Rome II Regulation in a methodological point of view, sets up a general rule, then a general exception to the general rule and ultimately, an escape clause where it stipulates that "where [...] the tort is manifestly more closely connected with a country other than that indicated in paragraphs 1 or 2 , the law of that other country shall apply." ${ }^{77}$ No doubt that the expression "manifestly more connected" leaves room for different interpretations and one of the problems that could be identified in this regard ${ }^{78}$ are cases that include a rental car. ${ }^{79}$ A classic case to refer to comes from UK's national jurisdiction, with Edmunds $v$ Simmonds ${ }^{80}$ where two persons having their habitual residence in England rented a car registered and insured in Spain.

The claimant then suffered damages because of the respondent's negligent driving. The question was whether to apply Spanish law, ${ }^{81}$ or alternatively, as the Queen's Bench Division decided, to apply English law instead. According to the court, even though the car was registered and insured in Spain "that was not of overwhelming weight" 82 and that the insurers "had to contemplate" 83 that due to the touristic nature of the area, the majority of their clients would be foreigners and hence, the quantification of damages could be made by another system of law rather than the Spanish one.

A problem here, ${ }^{84}$ with the connecting factors in hire car cases, seems to be the differences between national rules of damages quantifications. In Edmunds v Simmonds Spanish law did indeed foresee much lower damages for the injured party than English law. ${ }^{85}$ If the local insurance policy concluded with the rental of the car does not cover the difference between the two, the driver could potentially face the obligation to pay to the victim large sums of money. Therefore, as Von Hein suggests, in order to ensure that neither party gets overburdened, in

See in general Von Hein, Article 4..., op. cit.; See also Symeonides, op. cit.

Case C463/06 Odenbreit, ECLI:EU:C:2007:792.

Art 4.3 of Regulation (EC) No 864/2007 of the European Parliament and of the Council of 11 July 2007 on the law applicable to non-contractual obligations (Rome II) OJ L 199, 31. 7. 2007; on the interpretation of this article, see in particular Fentiman, $\mathrm{R}$ "The Significance of Close Connection" in Ahern, J. and Binchy, W. (eds.), The Rome II Regulation on the Law Applicable to NonContractual Obligations: A New International Litigation Regime, (2009) Martinus Nijhoff Publishers.

Von Hein, op. cit., p. 166.

Sieghörtner, R., Internationaler Mietwagenunfall - Zulassungsort als relevantes Anknüpfungskriterium?, NZV, Issue 16, 2003 , p 105.

Case (2001) 1 WLR 1003 (Queen's Bench).

Article 3 Convention on the law applicable to traffic accidents; Concluded at The Hague on 4 May 1971. Spain is a party to the Convention.

(2001) 1 WLR 1003, at 1004.

Ibid.

Von Hein, Article 4..., op. cit., p. 167.

Case (2001) 1 WLR 1003. 
such scenarios the escape clause could be triggered, with the justification that the country where the insurance policy is concluded has a manifestly closer connection to the tort than the country of common habitual residence. ${ }^{86}$ Nevertheless, the scenario becomes even more intricate if we realize that, as a party to the Hague Convention, Spanish courts would prioritize the application of the Article 3 of the Convention instead.

This brings us to one of the major problems encountered in Rome II Regulation: its co-existence with international conventions. ${ }^{87}$ Rome II Regulation strives to improve legal certainty and predictability of non-contractual obligations, but, as a number of scholars have righteously pointed out, ${ }^{88}$ the Regulation might be simply "flattering itself" ${ }^{89}$ As the next sections of this paper will point out, Rome II Regulation co-exists with the Hague Convention on the law applicable to traffic accidents (1971), ${ }^{90}$ which potentially gives rise to a patchwork of different connecting factors for the same situation, which would then lead to different applicable laws. The picture becomes even more complicated when we consider that the Motor Insurance Directives $^{91}$ (MIDs) are also applicable. ${ }^{92}$

\subsection{ARTICLE 28 OF THE ROME II REGULATION AND THE RELATIONSHIP WITH THE HAGUE CONVENTION}

What Rome II is striving to achieve is the predictability and certainty as to the law applicable, ${ }^{93}$ clearly following the rationales on the basis of which Savigny ${ }^{94}$ founded the conflictof-laws approach, one of which is the consistency of international decisions on private international law. Despite the will to ensure the uniform application of conflicts-of-laws, the picture in the European Union legal order is also dominated by other instruments which remain pertinent. In case of traffic accidents, The Hague Convention on the Law Applicable to Traffic Accidents (hereinafter The Hague Convention), remains in force and could potentially prevail over the Rome II Regulation, in the Member States that have ratified it (not less than 12). ${ }^{95}$

Article 28 of Rome II Regulation provides that it "shall not prejudice the application of international conventions to which one or more Member States are parties [...] when this

86 Von Hein, op. cit., p. 167; See also Staudinger, op. cit.

87 Article 28 of Regulation (EC) No 864/2007 of the European Parliament and of the Council of 11 July 2007 on the law applicable to non-contractual obligations (Rome II) OJ L 199, 31. 7. 2007.

Nagy, op. cit., pp. 93-108; Graziano, op. cit., pp. 425-429; Papettas, op. cit., pp. 297-321; Garriga, G., Relationships between Rome II and other international instruments, a commentary on Article 28 of the Rome II Regulation in Yearbook of Private International Law, Volume 9, 2007, pp. 137-148. [2000] OJ L181/65 and 2005/14/EC [2005] OJ L149/14, consolidated in Directive 2009/103/EC [2009] OJ L263/11. to non-contractual obligations (Rome II) OJ L 199, 31. 7. 2007. 
Regulation is adopted and which lay down conflict-of-law rules relating to non-contractual obligations." ${ }^{\prime 6}$ The exception that follows in paragraph 2 does not save the situation, since the Regulation is to take precedence over the international instruments, only if these are concluded exclusively between two or more MS. ${ }^{97}$ Rome II as such does not take precedence over The Hague Convention, since a few members to it, are not EU member states. ${ }^{98}$ In this scenario, the question of legal uncertainty, but also of forum shopping ${ }^{99}$ becomes a real threat.

In order to understand the possible gaps between the two regimes applicable in the territory of the EU, let us briefly explain the scheme comprised in The Hague Convention. Firstly, the Convention's general rule defines as the applicable law, the internal law of the State where the accident occurred ${ }^{100}$ and rests as such upon the principle lex loci delicti commissi. Even though the Rome II Regulation has narrowed down its general connecting factor, from the place of injury to the place of direct damage, applying as such the lex loci damni, both of these instrument's general rules lead in most of the cases to the designation of the same applicable law, since in most traffic accidents, the place of injury and the place of direct damage coincide. Differences exist, nevertheless, in the instruments' exceptions rules. As such, the Hague Convention does not recognize at all the connecting factor of common habitual residence of the parties, but rests in the principle of the legal domicile of the vehicle, also not at all used by the Rome II Regulation. ${ }^{101}$

Even though the above-mentioned clashes might apply finally to a minority of all the cross-border traffic accidents happening in the EU, the main purpose of Rome II Regulation seems to seriously be at a risk. In this legal landscape, as it is also constantly recalled by different scholars, ${ }^{102}$ Rome II Regulation has not been entirely successful in ensuring the harmonization of conflict-of-laws for non-contractual obligations. ${ }^{103}$ The fact that the above-mentioned applicable instruments in the field of traffic accidents might lead to the application of different internal laws, raises considerable challenges that both the victim and the tortfeasor (and his/her insurer) need to face.

From this perspective, and taking into consideration that the legal certainty about the applicable law is in the interests of all parties, be it a victim, an insurer or a tortfeasor, ${ }^{104}$ this article recalls that a denunciation of the Hague Convention could be an appropriate solution ${ }^{105}$

96 Article 28 of Regulation (EC) No 864/2007 of the European Parliament and of the Council of 11 July 2007 on the law applicable to non-contractual obligations (Rome II) OJ L 199, 31. 7. 2007.

97 Idem, paragraph 2.

98 Like for example Switzerland, the Balkans countries etc., see https://www.hcch.net/fr/states/hcch-members.

99 See amongst others Nagy, op. cit., pp. 93-108.

100 Article 3 Convention on the law applicable to traffic accidents; Concluded at The Hague on 4 May 1971.

101 Article 4 of Convention on the law applicable to traffic accidents; Concluded at The Hague on 4 May 1971.

102 See for example Nagy, op. cit.; Garriga, op. cit., pp. 137-148.

103 It is not the scope of this paper, but we remind that there exists also The Hague Convention on product liability, Convention of 2 October 1973 on the Law Applicable to Products Liability.

104 Von Hein, op. cit. p. 157; see also Hague Conference on Private International Law, Overview of The Hague Convention of 4 May 1971 on the Law Applicable to Traffic Accidents (2008).

105 Garriga, op. cit., p. 145. See also Pataut E, «De Bruxelles à La Haye, Droit international privé communautaire et Droit international conventionnel», in: Mélanges P. Lagarde, Paris (2005), at p. 675-676; Brière, C., Les conflits de conventions internationales en droit privé, Paris (2001), at p. 68 and p. 76. 
to finalize the mission of the harmonization of conflict-of-law rules in non-contractual obligations in the EU. This would avoid unnecessary burdens and confusion in cases where the applicable laws differ for the same situation, it would also avoid forum shopping and the "complex conflict-of-laws system" 106 created by the Hague Convention, which at the same time, could also be considered as "outdated" ${ }^{107}$

Until this happens, we could nevertheless imagine a possible "way out" from the application of the Hague Convention over the Rome II Regulation. ${ }^{108}$ This is enshrined in the Article 14 of Rome II Regulation: the principle of party autonomy. ${ }^{109}$ Even though not a very popular principle in non-contractual obligations ${ }^{110}$ and considered as under the risk to remain a "dead letter," 111 especially ex post party autonomy might be used from the parties to choose a common applicable law, even where there are cases falling within the jurisdiction of the Hague Convention. ${ }^{112}$ As such, the French Court of Cassation and the Austrian Supreme Court have decided to allow the application of party autonomy, according to the national PIL rules, even though the Hague Convention would be considered as applicable. ${ }^{113}$ And indeed, Article 14 Rome II Regulation could be indeed used as an effective tool to ensure the harmony of the decisions between the two different legal orders for traffic accidents in the EU. ${ }^{114}$

\section{INCONVENIENCIES AND EVOLUTIONS}

While the main function of Rome II Regulation is largely accepted as being the determination of the "applicable law"115 to non-contractual obligations, this section aims to analyze and understand the global approach of the Rome II and the methodology of determining such applicable law, towards the vulnerable parties, or in other terms, the victims of cross-border traffic accidents. Until now, this article has shown that the co-existence of Rome II Regulation and The Hague Convention could lead, although in a small number of cases, into the application of different substantive laws for the same situation, not answering as such the main objective of Rome II: legal predictability.

\footnotetext{
106 Garriga, op. cit., p. 145.

107 The Convention on the law applicable to traffic accidents was concluded at The Hague on 4 May 1971.

108 For this issue, see also Von Hein, op. cit., p. 158.

109 Article 14 of Regulation (EC) No 864/2007 of the European Parliament and of the Council of 11 July 2007 on the law applicable to non-contractual obligations (Rome II) OJ L 199, 31. 7. 2007.

110 See in general Kadner Graziano, Freedom to Choose..., op. cit.; see also Miaja de la Muela, A., Derecho internacional privado, Tomo segundo, parte especial, $10^{\text {th }}$ in Bouza Vidal (ed.), Madrid (1987).

111 Kadner Graziano, Freedom to Choose..., op. cit., p. 114

112 See Case Cour de cassation, chambre civile Audience publique du mardi 19 Avril 1988 in France and Austrian Supreme Court (OGH) 26 January 1995, (1995) in Austria.

113 See Von Hein, Article 4..., op. cit., p. 170.

114 Rather 3, since Denmark is not bound by the Rome II Regulation, see Von Hein, Article 4..., op. cit., p. 158.

115 Mills, A., "The Application of Multiple Laws Under the Rome II Regulation" in Ahern, J. and Binchy, W. (eds.), The Rome II Regulation on the Law Applicable to Non-Contractual Obligations: A New International Litigation Regime, (2009) Martinus Nijhoff Publishers at p. 133.
} 
Another "inconvenience" for the vulnerable parties could come from the choice of the European legislator to use the lex causae connecting factor to the quantification of damages, instead of practicing the dépeçage, or basically the application of multiple laws according to different elements of the tort.

What would then an application of the dépeçage principle entail and would it be suitable to envision a reform of the Rome II Regulation? Private international law rules are not the simplest ones to draft, as there are many elements to take into account such as simplicity, legal certainty, a convenient degree of flexibility, harmonization of international decisions, taking into account the party autonomy, if there is any, and a lot more elements of these kind that make striking a balance between different interests a real challenge. This section aims therefore to showcase whether Rome II should allow the application of multiple applicable laws, also taking into account the Odenbreit jurisprudence, as another example of what one could call the CJEU's judicial activism ${ }^{116}$ and from there explain the new elements that the use of forum actoris is bringing to the evolution of private international law in the EU.

It would be interesting if we could make the matters more tangible by providing examples, but after a while, we would realize that the interplay between the applicable laws of Rome II, The Hague Convention and the different exceptions to the rule, other than being arbitrary, are also confusing and equally unfavorable or favorable to the victim. For instance, take a Slovenian tourist in France, who becomes a victim of a traffic accident. Upon his return to his Member State of origin, he would be able to seize the national courts and to sue directly the insurer of the tortfeasor (provided that this is allowed by the law applicable to the non-contractual obligation or by the law applicable to the insurance contract). ${ }^{117}$ The Slovenian court would then apply the law of the state where the accident occurred, in other words the substantive French law in order to determine the tortfeasor civil liability and the quantification of damages for the victim. Between the Dintilhac nomenclature ${ }^{118}$ and the Mornet referential, ${ }^{119}$ the Slovenian judge, maybe unfamiliar with French law, may indeed experience some practical problems, but the overall method of damage quantification could in the end be favorable to the victim, if we agree arbitrarily that the compensation sums are more elevated in France than in Slovenia.

However, if the same tourist happens to have the accident in a country neighbor to France, say Germany, the law applicable would be the somehow strict substantive German law, ${ }^{120}$ both to the determination of civil liability and to the quantification of damages, provided that the court of the lex fori does not find that the tort is "manifestly more closely connected" with the substantive law of another country. ${ }^{121}$ Or alternatively, say a French tourist that suffers the same accident, but in Slovenia, could find himself or herself reimbursed according to Slovenian substantive law.

116 See Vyshka, op. cit., p. 541.

117 Article 18 of Regulation (EC) No 864/2007 of the European Parliament and of the Council of 11 July 2007 on the law applicable to non-contractual obligations (Rome II) OJ L 199, 31. 7. 2007.

118 Dintilhac J. P. (ed.), Rapport du groupe de travail chargé d'élaborer une nomenclature des préjudices corporels La Doc. Française (2005).

119 Mornet, B L'indemnisation des préjudices en cas de blessures ou de décès (2018) at http://www.ajdommagecorporel.fr/sites/www. ajdommagecorporel.fr/files/fichier-cv/RPC-BM-septembre\%20 20 18.pdf.

120 See for more on this Knetsch, op. cit., p. 989.

121 Article 4.3 of Regulation (EC) No 864/2007 of the European Parliament and of the Council of 11 July 2007 on the law applicable to non-contractual obligations (Rome II) OJ L 199, 31. 7. 2007. 
In any example that we might think of, there will be a degree of dissatisfaction according to the situation that the parties find themselves. In the first case, the Slovenian tourist would be happy to receive a greater amount of compensation according to the French law, but in the second one, the strict German rules might not be very welcomed. The application of a "harmonized" conflict-of-laws rule can effectively lead to inconsistencies, according to the economic and social differences between Member States of the European Union. ${ }^{122}$ When the French court finds itself, as per the above-mentioned example, obliged to apply the foreign Slovenian substantive laws of damage quantification, a question that would normally rise is: how to avoid and circumvent the determination of Slovenian law as the applicable law?

A few options arise in this regard. The first one is following the example of the English characterization of damage quantification as a "procedural matter". ${ }^{123}$ A procedural characterization would in other words mean that the lex fori will be applicable to a part of the case (i.e. the quantification of damages) "without any reference to the rules of other jurisdictions that have contact with the parties and the transaction." 124

Thus, if we take the example of Chaplin v. Boys, ${ }^{125}$ a British citizen had caused corporal damage to another British citizen during their stay in Malta. The law of the country where the damage occurred, that is Maltese law, did not provide damages for pain and suffering, as it is provided alternatively in English law. ${ }^{126}$ Even though the conflict-of-laws at the time was lex loci delicti, which would lead to the designation of Maltese law as applicable to the damage quantification, the English court decided nonetheless to apply English law instead. The result was inherently the same, but the arguments different. For example, the Lords Donovan and Guest argued that the damage quantification for pain and suffering was a procedural issue and governed as such by the lex fori. ${ }^{127}$ On the other hand, Lord Pearson thought that the damages should not be characterized as procedural, but that English law should be nevertheless applicable to the damage quantification since the plaintiff is suing in England after all. ${ }^{128}$ Nevertheless, as it stands, some scholars believe that it would be a mistake to characterize the issue of damage quantifications as a procedural one, since problems of forum shopping might arise stronger than ever. ${ }^{129}$ Moreover, a classification as procedural of the issues of damage quantification would be contrary to the Article 15 of the Rome II Regulation, which states clearly that the assessment of damage is governed by this present Regulation. ${ }^{130}$

Secondly, Rome II in Article 26 provides that "the application of a provision of the law of any country specified by this Regulation may be refused only if such application is manifest-

\footnotetext{
122 Knetsch, op. cit., p. 989; Rigaux, F. and Fallon, M., Droit international privé, Larcier (2005).

123 See Weintraub, R., "Discretion versus Strict Rules in the field of Cross-Border Torts" (2005) at https://dianawallis.org.uk/cy/ document/seminar-14-march/weintraub-discretion-vs-strict-rules-in-the-field-of-cross-border-torts\#documentp 3.

124 See Weintraub, op. cit., p. 3; See also Restatement (Second) of Conflict of Laws, Para. 122 comment b (1971) and Case Guaranty Trust Co. v. York, 326 U.S. 99, 107 (1945).

125 See Case Boys v Chaplin [1971] AC 356

126 For a comment on this see Reese, W. L. M., Choice of Law in Tort Cases. Chaplin v. Boys (England: Court of Appeal and House of Lords), The American Journal of Comparative Law, Vol. 18, No. 1 (Winter, 1970), pp. 189-194.

127 Case Boys v Chaplin [1971] AC 356, at 382 and 383.

128 Case Boys v Chaplin [1971] AC 356, at 398.

129 See Weintraub, op. cit., p. 7.

130 Knetsch, op. cit., p. 991.
} 
ly incompatible with the public policy of the forum."131 However, it does not seem probable that a court will refuse the application of a foreign law only because it does not sufficiently compensate the victim, as it would be according to the law of the forum. Moreover, according to a view in scholarship, ${ }^{132}$ the concept of public policy in private international law is going through a period of "erosion", its scope of application being narrowed down more and more each year. ${ }^{133}$ In the end, public policy remains a tool that could be potentially used to apply the law of the forum instead, but de facto, it seems that Article 26 Rome II Regulation will simply remain dead letter.

A somewhat more feasible option could be relying on that little flexibility that Rome II provides and the use of its escape clause. If we turn to the previously mentioned hire car case in Edmunds $v$. Simmonds ${ }^{134}$ there is a risk for the driver to not be covered in total by the local insurance policy, if the Court designs as applicable law British law according to the common habitual residence rule (Article 4.2 Rome II Regulation). ${ }^{135}$ Academics in this case tend to argue that the place of registration of the vehicle could lead to the consideration of the tort ultimately as "manifestly more connected" 136 to the country of registration than to the country of common habitual residence. Even though it might sound an overarching interpretation, it still exists as a possibility. In any case, Rome II Regulation, even though use the strict terms of "manifestly more closely connected" it also states that this might be based "in particular" on pre-existing relationships between the parties. With this interpretation, seems like the competent Court's discretion plays also a major role.

With somehow a vague exception of the third "way out", the main position is that remedies to the problems posed by the application of the lex causae to the quantification of damages are quite limited. ${ }^{137}$ Victims and vulnerable parties up until this analysis can be susceptible to suffer from legal insecurity. Nevertheless, in the next subsections, this article explores the evolutions in the non-contractual obligations in the EU, following the influence of the CJEU with its Odenbreit jurisprudence as a quite liberal and victim-centered approach and on the possibility of applying the principle of dépeçage to dissociate the applicable laws for the damage quantification on one hand and for the civil responsibility on the other.

\subsection{APPLICABILITY OF MULTIPLE LAWS}

Dépeçage, or else known as issue by issue analysis ${ }^{138}$ is a term used to express the availability of using multiple applicable laws to govern different and distinct elements of a non-con-

131 Article 26 of Regulation (EC) No 864/2007 of the European Parliament and of the Council of 11 July 2007 on the law applicable to non-contractual obligations (Rome II) OJ L 199, 31. 7. 2007.

132 Knetsch, op. cit., p. 990.

133 Ibid.

134 See section 2.b of this article.

135 Von Hein, Article 4..., op. cit., p. 167; see also Staudinger, A “Rome II and traffic accidents” (2005) 5 EuLF 1-61.

136 Von Hein, op. cit., p. 167.

137 Knetsch, op. cit., p. 992.

138 For more on this see Mills, The Application..., op. cit. 
tractual obligation. For example, as it was mentioned earlier in this article, a dépeçage would mean applying different laws for the issue of defining the civil liability of the tortfeasor and for the distinct issue of subsequently determining the modalities or availability of damages for the same non-contractual obligation.

The dépeçage is plainly prohibited by the Rome II Regulation and not only in its general rule in Article 4, applicable to traffic accidents, but also in other special provisions, like product liability in Article $5^{139}$ or unjust enrichment, in Article $10 .{ }^{140}$ However, when drafting the Rome II provisions, the idea of allowing issue by issue analysis was not entirely off the table, as the European Parliament's draft provided that "in resolving the question of the applicable law, the court seized shall, where necessary, subject each specific issue of the dispute to separate analysis." ${ }^{141}$ For the EP and more specifically for its Committee on Legal Affairs, the essential would be that "the courts are provided with a clear instrument which allows them the necessary flexibility in order to do justice to parties in individual cases." ${ }^{142}$

Confronting on the other hand, the Commission's proposal that did not include any provision for an issue by issue analysis, ${ }^{143}$ this view of the European Parliament seems interesting if one would envision the need for a reform in the Rome II Regulation. First of all, dépeçage should not be considered as a "device through which courts can avoid unattractive applicable laws" ${ }^{144}$ Private international law provisions are generally conceptualized as purely objective norms that do not take into account the end results of the application of different substantive laws, but it seems that into its proposal, the EP was largely influenced by the United States concept of conflict-of-law rules: an outcome-based analysis. That is why, like Von Hein, ${ }^{145}$ we tend to believe that the final outcome of Rome II responds in priority to the "conflicts justice" instead of material or substantive justice. ${ }^{146}$

The outcome-based analysis is what actually founded the US conflict-of-laws revolution ${ }^{147}$ and the EP proposal suggested that at least the same attempt was made for the European Union. However, a European court's discretion to choose between applicable laws with a tele-

139 Article 5.2 of Regulation (EC) No 864/2007 of the European Parliament and of the Council of 11 July 2007 on the law applicable to non-contractual obligations (Rome II) OJ L 199, 31. 7. 2007.

140 Article 10.4 of Regulation (EC) No 864/2007 of the European Parliament and of the Council of 11 July 2007 on the law applicable to non-contractual obligations (Rome II) OJ L 199, 31. 7. 2007.

141 Position of the European Parliament adopted at first reading on 6 July 2005 with a view to the adoption of Regulation (EC) No .../2005 of the European Parliament and of the Council on the law applicable to non-contractual obligations ("ROME II") at Article 4.4.

142 See European Parliament Committee on Legal Affairs, Report on the proposal for a regulation of the European Parliament and of the Council on the law applicable to non-contractual obligations ("Rome II") (COM (2003)0427 - C5-0338/2003 2003/0168(COD)) Amendment 38.

143 European Commission, Proposal for a Regulation of the European Parliament and the Council on the Law Applicable to NonContractual Obligations (“Rome II") 22. 7. 2003 COM (2003) 427 final, 2003/0168.

144 Mills, The Application..., op. cit., p. 138.

145 Von Hein, Article 4..., op. cit.

146 See also Symeonides, S., "American Conflicts Law at the Dawn of the 21st Century" (2000) 37 Willamette L. Rev. 1; Symeonides, Rome II..., op. cit.

147 See Cavers, D. F., "A Critique of the Choice of Law Problem" (1933) 47 Harvard L. Rev. 173; see also in general, Symeonides, S., The American Choice of Law Revolution: Past, Present and Future, (2006) Brill. 
ological end in mind is hardly accepted by the Member States. ${ }^{148}$ Moreover, since the Regulation's main objectives were (and continue to be) legal predictability and certainty, the issue of dépeçage was rapidly seen as inconsistent. ${ }^{149}$

However, the fact that dépeçage has been an issue of discussion, encourages us in this paper to explore the opportunities and ideas for a possible step further in the Rome II Regulation. It would be necessary nevertheless, to strike a balance between vulnerable parties' protection and policy uncertainty, which dépeçage undoubtedly gives rise to. If we take the example of the USA, it was popular amongst the critics of the lex loci delicti connecting factor and the part of academia that promoted the "interest analysis" 150 of a specific case to campaign for the use of the dépeçage principle. ${ }^{151}$ Nevertheless, it not impossible to rely upon the dépeçage and also to follow the interests of no party in particular, in circumstances where the conflictof-laws is based only on objective connecting factors, as it is usually the case. ${ }^{152}$

Uncertainty has reigned upon the dépeçage in conflict-of-laws rules, ${ }^{153}$ but the overall exclusion of it from the Rome II Regulation might have not been the right decision. According to Symeonides, ${ }^{154}$ for example, a great opportunity for revolutionizing the conflict-of-laws in Europe was clearly missed. There would also be, in this regard, insufficiency as to the flexibility of the rules in Rome II. In a critique of the general rule, Symeonides believes that Article 4.1 and 4.2 of the Regulation can deliver unsuitable results and that Article 4.3 would be deemed as applicable in very few cases, since it is unclear what and how "a manifestly more connected" country would emerge in a non-contractual obligation. As accepted earlier in this paper, Article 4.3 risks remaining a dead letter provision, due to its inflexibility and narrowness. ${ }^{155}$ In this regard, dépeçage would come to rescue because arguably, an element of the non-contractual obligation, like the damage quantification, could be more connected with the legal order of a specific country, than the whole and undivided non-contractual obligation. ${ }^{156}$

On the other hand, the argument that there should be only one applicable law to govern all the elements of the non-contractual obligation prevails and is stronger than ever. ${ }^{157}$ Mills for example, illustrates this choice by explaining that the same law should be applicable to liability and damages, because most of the cases, the tort policies of a country, have a balance between

\footnotetext{
148 Mills, The Application..., op. cit., p. 139.

149 Idem. Though it is interesting, because Rome II still allows the application of previous international instruments, like Hague Conventions via Article 28, which as this article testifies, does not answer to the objectives of legal predictability and certainty.

150 See Mills, The Application..., op. cit., p. 143.

151 See for example the American Law Institute's First Restatement of Conflict of Laws in 1934, section 377; see also Mills, op. cit., p. 143. For an overview on dépeçage see Stevenson, C. G., "Dépeçage: Embracing Complexity to Solve Choice-of-Law Issues" (2003) 37 Indiana L. Rev. 303; Reese, W. L. M., "Dépeçage: A Common Phenomenon in Choice of Law" (1973) 73 Columbia L. Rev. 58; Ena, M., "Choice of Law and Predictability of Decisions in Products Liability Cases (2007) 34 Fordham Urban L. J. 1417; see also Wilde, C. L., "Dépeçage in the Choice of Tort Law" (1968) 41 S. California L. Rev. 329.

152 Mills, op. cit., p. 143.

153 Mills, op. cit., p. 144.

154 See in general Symeonides, op. cit., p. 173.

155 See also Mills, The Application..., op. cit., p. 145

156 Carruthers, J and Crawford, E., Variations on a Theme of Rome II. Reflections on Proposed Choice of Law Rules for Non-Contractual Obligations: Part II, (2005) 9 Edinburgh L. Rev. 238

157 Mills, op. cit., p. 146.
} 
these two elements: a low threshold of liability would entail low damages and vice-versa. ${ }^{158}$ While this is of course true, in cross-border traffic accidents one cannot insist upon the fact that differences between EU Member States' healthcare costs for example, should completely be left aside. It sounds logical that an injured French tourist while in Slovenia should be reimbursed according to the costs of the healthcare system that he belongs to in his state of origin.

In these cases, this article suggests that the use of dépeçage could be a good mean to ensure proper compensation for the injured party, "by allowing for the application of a different applicable law to the question of damages." ${ }^{59}$ This, in other terms, would simply require a formalization of Recital 33 previously mentioned, which per se is an unsatisfactory solution to the EP's proposal, due to its non-binding and merely descriptive nature. The present choices therefore do not seem satisfactory, especially in the light of enhanced protection for the injured party that the Odenbreit jurisprudence brings upon the table.

\subsection{FORUM ACTORIS - EVOLUTIONS IN EUROPEAN PIL}

From the above analysis, it seems perfectly normal that the judicial policy of Rome II will have its critics. The application of a unique law to the determination of the civil liability and to the quantification of damages cannot be freely disregarded by the competent court. On the other hand, the liberal (and somehow activist) approach of the CJEU in determining the jurisdiction and in establishing the right for a direct action of a third party (forum actoris) in the courts of a Member State where he/she is domiciled, it seems to us, like a preliminary conclusion, that the CJEU is pointing out towards a more liberal and flexible new approach for the Rome II Regulation.

As such, in the Odenbreit ${ }^{160}$ case, the CJEU decided that Article 9(1) of Brussels I Regulation on jurisdiction and enforcement of judgements in civil and commercial matters is to be interpreted as meaning that "the injured party [should be permitted] to bring an action directly against the insurer before the courts for the place in a Member State where the injured party is domiciled, provided that a direct action is permitted and the insurer is domiciled in a Member State." ${ }^{161}$

Now, it is true that between an insurance company and its insureds, the insurance policy commonly includes a jurisdiction clause, which nevertheless, is not to be deemed as binding upon injured third parties, as recently decided by CJEU in Assens Havn v Navigators Management. ${ }^{162}$ The jurisprudence of CJEU in this regard, seems to point out that insurance companies do not have unlimited control over the Member States' jurisdictions that will be potentially seized by an injured third party to hear the claim, nor can they be sure that the jurisdiction

\footnotetext{
158 Ibid.

159 Ibid.

16o Case C-463/06 Odenbreit, ECLI:EU:C:2007:792.

161 Case C-463/06 Odenbreit, ECLI:EU:C:2007:792, para. 31

162 Case C-368/16 Assens Havn ECLI:EU:C:2017:546.
} 
clauses included in the insurance policy will be found applicable. Therefore, the implications for insurance companies as well should not be overlooked.

For instance, in the Assens Havn case, (even though it is not a case involving a traffic accident, the same reasoning can be applied by analogy) a Swedish vessel that was insured by Navigators Management, a British insurance company, caused damage to a quay in Denmark. The Danish owner directly sued the insurance company in its Member State of residence, only to find out that the Danish courts, in first instance, dismissed the action on the grounds that the insurance policy between the tortfeasor and Navigators Management provided for exclusive competence of the English jurisdiction.

The Danish Supreme court, then asked a preliminary question to the CJEU, asking whether the provisions of such insurance policies were also binding for a third party. For the CJEU, this matter was long discussed with the case Société financière et industrielle du Peloux v AXA Belgium $^{163}$ and it simply proceeded with "extending" the reasoning to injured third parties who bring a direct action against the insurer. The Court's commitment to the protection of weaker parties can be seen especially where it states that "the situation of a third party victim of insured damage is even farther removed from the contractual relationship that an insured beneficiary who did not expressly consent to that agreement." ${ }^{164}$ In a nutshell, the provisions of a specific court's jurisdiction on an insurance policy are not binding towards an injured third party, which is a good step forward into ensuring the third parties' adequate protection.

On the other hand, this certainly means that insurance companies domiciled the EU can be found with an obligation to respond to a direct action in front of virtually all jurisdictions of EU Member States, according to the place where their insureds caused damage. As such, they cannot rely upon their insurance policy provisions on a specific jurisdiction when trying to evade the application of an unfamiliar national jurisdiction. ${ }^{165}$

The protection of injured parties or "contractually weaker parties" 166 has indeed been one of the priorities of CJEU in examining a considerable number of judgements in the field of conflict-of-laws and jurisdiction. ${ }^{167}$ As it has been clear up until now in principle the weaker parties enjoy a right of forum actoris that is the right to bring direct action against an insurer before the courts of habitual residence. ${ }^{168}$ Ultimately they are also protected from actions initiated by the insurer, since the insurers can bring "proceedings only in the courts of the Mem-

163 Case C-112/03 Société financière et industrielle du Peloux ECLI:EU:C:2005:280.

164 Case C-368/16 Assens Havn ECLI:EU:C: 2017:546, at para. 39.

165 Moreover, this is against the principles of effectiveness of Brussels I and violates the mutual trust between Member States, see Case C-159/02 Turner v Grovit ECLI:EU:C:2004:228.

166 Dominelli, S., Direct Actions of 'Injured Parties' in the Brussels Ia Regulation: The Pawel Hofsoe Case of the Court of Justice of the European Union as an Expression of Legal Pragmatism, EuLF, Issue 2, 2018, 29-60, at p. 30.

167 See in general Case C-463/06, FBTO Schadeverzekeringen NV v Jack Odenbreit; Case C-347/08 Vorarlberger Gebietskrankenkasse $v$ WGV-Schwäbische Allgemeine Versicherungs AG; Case C-111/09 ýeská podnikatelská pojišșovna as, Vienna Insurance Group v Michal Bilas; Case C-521/14 SOVAG - Schwarzmeer und Ostsee Versicherungs-Aktiengesellschaft v If Vahinkovakuutusyhtiö Oy; Case C-340/16 Landeskrankenanstalten-Betriebsgesellschaft - KABEG v Mutuelles du Mans assurances - MMA IARD SA; Case C-368/16 Assens Havn $v$ Navigators Management (UK) Limited. Specifically, for direct actions see Joined Cases C-359/14 and C-475/14, "ERGO Insurance" SE v "If P\&C Insurance" AS and "Gjensidige Baltic" AAS v "PZU Lietuva" UAB DK; Case C-240/14 Eleonore PrüllerFrey $v$ Norbert Brodnig and Axa Versicherung AG. 
ber State in which the defendant is domiciled." 169 The concept of an "injured party" is present therefore in Brussels Ia Regulation, where the right to a forum actoris is expressly provided. ${ }^{170}$ However, Brussels Ia seems to remain silent (and the CJEU continued this silence) ${ }^{171}$ in matters determining which forum can the injured party seize. Can it be "their own protective forum"172 or are there options in choosing between the courts of their habitual residence or the courts of the country where the insurer is domiciled. Practically, in Brussels Ia Regulation, direct action is allowed only where "such direct actions are permitted", ${ }^{173}$ but which law should recognize a direct action is still unclear. ${ }^{174}$ Where applicable, the rules of Rome II Regulation seem to be more specific: a direct action is possible if recognized by the law applicable to the non-contractual obligation or by the law applicable to the insurance contract. ${ }^{175}$

This brings us to Article 18 of Rome II Regulation, the provision expressly regulating the right of direct action in non-contractual obligations: "The person having suffered damage may bring his or her claim directly against the insurer of the person liable to provide compensation if the law applicable to the non-contractual obligation or the law applicable to the insurance contract so provides." ${ }^{176}$ Different interpretations of this article circulate in the academic debate. There are scholars that think of this provision as a complimentary rule, where applicable, to the Brussels Ia vague approach on direct actions, ${ }^{177}$ but there is also the feeling that this provision seems to be ambiguous and somewhat unhelpful."178

In a very direct interpretation, the provision does not say much as regards the applicable law for the whole action, but it simply sets out the applicable law that would permit the existence or not of a right for direct action. ${ }^{179}$ If the provision was to be read as containing a real choice-of-law for the injured party between the law applicable to the non-contractual obligation or the law applicable to the insurance contract, ${ }^{180}$ the situation becomes much more interesting. Since the first scenario is pretty much the rule (the MIDs oblige EU Member States to

169 Article 14 Regulation (EU) No 1215/2012 of the European Parliament and of the Council of 12 December 2012 on jurisdiction and the recognition and enforcement of judgments in civil and commercial matters (recast) (Brussels Ia) OJ L 351/1, 20. 12. 2012.

170 Article 13.2 of Regulation (EU) No 1215/2012 of the European Parliament and of the Council of 12 December 2012 on jurisdiction and the recognition and enforcement of judgments in civil and commercial matters (recast) (Brussels Ia) OJ L 351/1, 20. 12. 2012.

171 Dominelli, op. cit., p. 30.

172 Ibid.

173 Art 13.2 of Regulation (EU) No 1215/2012 of the European Parliament and of the Council of 12 December 2012 on jurisdiction and the recognition and enforcement of judgments in civil and commercial matters (recast) (Brussels Ia) OJ L 351/1, 20. 12. 2012.

174 This brings us to the applicable rules of Rome II regulation in art 18, to be discussed further in this article. See also Dominelli, op. cit., p. 30.

175 See Case C-240/14 Eleonore Prüller-Frey v Norbert Brodnig and Axa Versicherung AG, para. 37.

176 Article 18 Regulation (EC) No 864/2007 of the European Parliament and of the Council of 11 July 2007 on the law applicable to non-contractual obligations (Rome II) OJ L 199, 31. 7. 2007.

177 See in general Dominelli, op. cit., pp. 29-60.

178 Papettas, op. cit., p. 308.

179 Ibid.

180 As it is read by, amongst others, Dickinson, A The Rome II Regulation the Law Applicable to Non-Contractual Obligations (2008) Oxford University Press; Von Hein, op. cit. 
recognize the right of a direct action), ${ }^{181}$ the injured party would have the possibility to choose between the two scenarios, the "law which is more favorable to him"182 leading therefore to the possibility of an alternative connection. The CJEU has not yet interpreted this provision, but this might be at least the tendency in which it will lean upon, since it is the interpretation most favorable to the victim.

Another issue that relates to Article 18, regardless to its interpretation as establishing a choice for the victim or simply creating a right of direct action in non-contractual obligation, is the relationship of the insurer with the insurance policy (contract) and the tortuous event. ${ }^{183}$ Normally, in a scenario of a direct action, the non-contractual obligation will fall into the scope of Rome II Regulation, but would the insurer be allowed to rely on the provisions of the contract that set out another competent jurisdiction? ${ }^{184}$ The answer seems simple, if we consider that Assens Havn case applies by analogy, but this still remains an open question. ${ }^{185}$

\section{CONCLUSIONS}

Overall, the situation of the injured parties and of the victims as regards their protection in cases of cross-border traffic accidents, as governed by the rules of European private international law (Rome II Regulation overwhelmingly), does not appear to be entirely satisfactory. First of all, the objectives of legal predictability and certainty are clearly put into question with the co-existence between Rome II Regulation and The Hague Convention on the Law Applicable to traffic accidents, which remains in force in $12 \mathrm{MS}$ of the EU and is given priority from Article 28 of the Rome II Regulation.

A desired unification of conflict-of-laws rules regarding non-contractual obligations has, as such, not been reached, but possible options can (and should) be undertaken in order to ensure a unified approach in front of determining a law applicable to non-contractual obligations: either a denunciation of The Hague Convention ${ }^{186}$ or a reformulation of Article 28 of the Rome II, so that the Regulation is given precedence over the Convention.

On the contrary of this co-existence and possibility of having different applicable laws according to the state where the damage occurs, Rome II Regulation, on the other hand has kept a very unitary approach as regards the applicable law to the quantification of damages and the determination of civil liability. This particular choice could be the result of the unitary approach being dominant in many MS national rules, ${ }^{187}$ but as this paper has been advocating,

\footnotetext{
181 Article 3 of Directive 2000/26/EC of the European Parliament and of the Council of 16 May 2000 on the approximation of the laws of the Member States relating to insurance against civil liability in respect of the use of motor vehicles and amending Council Directives 73/239/EEC and 88/357/EEC (Fourth motor insurance Directive) OJ L 181, 20. 7. 2000, p. 65-74.

182 Papettas, op. cit., p. 308.

183 Papettas, op. cit., p. 310.

184 See in general, Papettas, op. cit., pp. 297-321.

185 Aside the CJEU jurisprudence, the MIDs also prohibit insurers to rely upon the provisions of insurance policies against third parties, see Papettas, op. cit., p. 310.

186 Amongst others, see for this recommendation also Garriga, op. cit., pp. 137-148.

187 Kadner Graziano, La responsabilité..., op. cit.
} 
a dépeçage at least in the level of cross-border traffic accident could be beneficiary in order to enhance the protection levels for the injured parties. With the actual regime, these injured parties could potentially face very low sums in compensation for their damages, often disproportionate to the actual costs of healthcare in their national systems.

The drafting of conflict-of-law rules in non-contractual obligations involves without any doubt striking a difficult balance between different policy considerations, ${ }^{188}$ and the analysis that this article has proposed acknowledges that legal predictability and certainty are important policy choices that European private international law instruments focuses on. However, in cross-border traffic accidents, a real mechanism should be put into place by the Rome II Regulation, allowing for a fragmentation between the applicable law of the tortfeasor civil liability and to the applicable law of the quantification of damages. In the current state of art, there are no legal "ways out" this unitary approach that would favor the traffic accident victims, either than a broad and maybe overreaching interpretation of Article 4.3 Rome II Regulation, or the non-binding Recital 33 of the same instrument.

The need for a degree of flexibility should therefore, be taken into consideration in order to make sure that the conflict-of-law rules fit the needs of specific cases, giving way to the originally United States approach of interest analysis. It should be mentioned, nevertheless, that Rome II Regulation at least includes the principle of party autonomy, somehow unknown to the realm of non-contractual obligation, but with the potential of becoming "one of the most important rules in tort, just as it has always been in contract". ${ }^{189}$

Last but not least, comes the CJEU's liberal approach to the use of forum actoris through the Odenbreit case and the will of the Court to act (once again) ${ }^{190}$ as the highest instance that protects the vulnerable parties in situations not favorable to their position, even though this line of jurisprudence would mean turmoil in the national litigation processes of non-contractual obligations and damage quantification. ${ }^{191}$

\section{BIBLIOGRAPHY}

1. Adensamer, M., Der Verkehrsunfall im Licht der Rom-II-Verordnung, Zeitschrift für Verkehrsrecht, Vol. 51, Issue 12, 2006.

2. Bona, M., Personal Injuries, Fatal Accidents and Rome II: Can the Law of the Country where the Victim Suffers Provide Full and Fair Compensation, In: Malatesta, A. (ed.), The Unification of Choice of Law Rules on Torts and other Non-Contractual obligations in Europe: the "Rome II proposal", CEDAM, Padova, 2006.

3. Brière, C., Les conflits de conventions internationales en droit privé, pro P. Courbe, Paris, L.G.D.J, 2001, pp. 68,76 .

\footnotetext{
188 Mills, The Application..., op. cit., p. 151.

189 Kadner Graziano, Freedom to Choose op. cit., p. 132.

190 See in general cases like Case C-34/09 Ruiz Zambrano, EU:C:2011:124; Case C-148/02 Garcia Avello, EU:C:2003:539; see also Vyshka, op. cit., pp. 533-550.

191 In Germany for instance, see in general Knetsch, op. cit., p. 979-1018; see also Wasserer, S "Paradigmenwechsel in der internationalen Zuständigkeit für Direktklagen: Wohnsitzgerichtsstand des Geschädigten bei Klagen gegen ausländische KfzHaftpflichtversicherungen", European Law Reporter (2008) pp. 143-147.
} 
4. Brière, C., Le règlement (CE) $n$ 864/2007 du 11 juillet 2007 sur la loi applicable aux obligations non contractuelles ("Rome II"), JDI, 2008, pp. 31-74.

5. Carruthers, J. M., Crawford, E. B., Variations on a Theme of Rome II. Reflections on Proposed Choice of Law Rules for Non-Contractual Obligations: Part II, Edinburgh Law Review, Vol. 9, No. 2, 2005, pp. 238-266.

6. Cavers, D. F., A Critique of the Choice-of-law Problem, Harvard Law Review, Vol. 47, No. 2, 1933, pp.173-208.

7. Davies, G., Does the Court of Justice own the Treaties? Interpretative pluralism as a solution to over-constitutionalization, European Law Journal, Vol. 24, No. 6, 2018, pp. 358-375.

8. Dickinson, A., The Rome II Regulation: The Law Applicable to Non-Contractual Obligations, Oxford: Oxford University Press, 2008, pg. 7.

9. Dintilhac J. P., (ed.), Rapport du groupe de travail chargé d'élaborer une nomenclature des préjudices corporels, 2005. Available at:

http://www.ladocumentationfrancaise.fr/rapports-publics/064000217/index.shtml [Last accessed March $11^{\text {th }}$, 2020].

10. Dominelli, S., Direct Actions of 'Injured Parties' in the Brussels Ia Regulation: The Pawe Hofsoe Case of the Court of Justice of the European Union as an Expression of Legal Pragmatism, The European Legal Forum (Forum iuris communis Europae), No. 2, 2018, pp. 29-60.

11. Dornis, T. W., When in Rome, do as Romans do? - A defense of lex domicilii communis in the Rome II Regulation, The European Legal Forum, 2007, pp. 152-159.

12. Ena, M., Choice of Law and Predictability of Decisions in Products Liability Cases, Fordham Urban Law Journal, Vol. 34, 2007, p. 1417.

13. Fentiman, R., “The Significance of Close Connection”, In: Ahern, J., \& Binchy, W. (eds.), The Rome II Regulation on the Law Applicable to Non-Contractual Obligations: A New International Litigation Regime, Brill Nijhoff, 2009, pp. 85-94.

14. Garcimartín Alférez, F. J., The Rome II Regulation: on the way towards a European private international law code, In: The European Legal Forum, 2007, pp. 77-91.

15. Garriga, G., Relationships between Rome II and other international instruments, a commentary on Article 28 of the Rome II Regulation, Yearbook of Private International Law, Volume 9, 2007, pp. 137-148.

16. Giardina, A., Italy: Law Reforming the Italian System of Private International Law, International Legal Materials, Vol. 35, No. 3, 1996, pp. 760-782.

17. Graziano, T. K., The Rome II Regulation and The Hague Conventions on Traffic Accidents and Product Liability - Interaction, conflicts and future perspectives, Nederlands Internationaal Privaatrecht (NIPR), 2008, pp. 425-429.

18. Graziano T. K., La responsabilité délictuelle en droit international privé européen, Bâle/Genève/Munich - Bruxelles - Paris: Helbing Lichtenhahn - Bruylant, L.G.D.J, 2004.

19. Graziano, T. K., General Principles of Private International Law of Tort in Europe, In: Basedow, J., Baum, H. and Nishitani, Y. eds., Japanese and European private international law in comparative perspective, Vol. 48, 2008, Mohr Siebeck.

20. Graziano, T. K., Freedom to choose the applicable law in Tort - Articles 14 and 4 (3) of the Rome II Regulation, In: Ahern, J., Binchy, W. (eds.), The Rome II Regulation on the law applicable to non-contractual obligations: A New International Litigation Regime, Brill Nijhoff, 2009, pp. 113-132.

21. Graziano, T. K., Gemeineuropäisches internationales Privatrecht: Harmonisierung des IPR durch Wissenschaft und Lehre (am Beispiel des ausservertraglichen Haftung für Schäden), Mohr Siebeck, Vol 73, 2002, pp. 379-388. 
22. Hay, P., Contemporary Approaches to Non-Contractual Obligations in Private International Law (Conflict of Laws) and the European Community's "Rome II" Regulation, The European Legal Forum, 2007, pp. 137-152.

23. Hohloch, G., Place of Injury, Habitual Residence, Closer Connection and Substantive Scope - The Basic Principles, Yearbook of Private International Law, Vol. 9, 2007, pp. 1-18.

24. Joerges, C., The Challenges of Europeanization in the Realm of Private Law: A Plea for a New Legal Discipline, Duke Journal of Comparative and International law, Vol 14, No. 149, 2004, pp. 149-196.

25. Junker, A., Das Internationale Privatrecht der Straßenverkehrsunfälle nach der Rom II-Verordnung, Juristenzeitung, 2008, pp.169-178.

26. Kozyris, P. J., Rome II: Tort Conflicts on the Right Track! A Postscript to Symeon Symeonides' "Missed Opportunity", The American Journal of Comparative Law, Vol. 56, No. 2, 2008, pp. 471-498.

27. Knetsch, J., La réparation du dommage extracontractuel en droit international privé, Le droit à l'épreuve des sciècles et des frontières, Lextenso, 2018, pp. 979-1018.

28. Kuipers, J. J., Cartesio and Grunkin-Paul: Mutual recognition as a vested rights theory based on party autonomy in private law, European Journal of Legal Studies, Vol. 2, 2008, pp. 66-96.

29. Malatesta, A. (ed.), The Unification of Choice of Law Rules on Torts and Other Non-Contractual Obligations in Europe, CEDAM, Milan 2006.

30. Miaja de la Muela, A., Derecho internacional privado, Tomo segundo, parte especial, 10th ed. (by Bouza Vidal), Madrid, 1987.

31. Mills, A., The Application Of Multiple Laws Under The Rome II Regulation. In: Ahern, J., \& Binchy, W. (eds.), The Rome II Regulation on the law applicable to non-contractual obligations: A New International Litigation Regime, Brill Nijhoff, 2009, pp. 133-152.

32. Mills, A., Rediscovering the public dimension of private international law, Nederlands Internationaal Privaatrecht (NIPR), Vol. 30, 2012, pp. 371-375.

33. Mornet, B., L’indemnisation des préjudices en cas de blessures ou de décès, 2018. Available at: http:// www.ajdommagecorporel.fr/sites/www.ajdommag ecorporel.fr/ files/fichier-cv/RPC-BM-septembre\%202018.pdf [Last accessed March 11 $\left.{ }^{\text {th }}, 2020\right]$.

34. Nagy, C., The Rome II Regulation and Traffic Accidents: Uniform Conflict Rules with some Room for Forum Shopping - How so? Journal of Private International Law, Vol. 6. No. 1, 2010, pp. 93-108.

35. Papettas, J., Direct Actions against Insurers of Intra-Community Cross-Border Traffic Accidents: Rome II and the Motor Insurance Directives, Journal of Private International Law, Vol. 8, No. 2, 2012, pp. 297-321.

36. Pataut, E., 2005. De Bruxelles à La Haye. Droit international privé communautaire et droit international privé conventionnel. Le droit international privé: esprit et méthodes, Mélanges en l'honneur de P. Lagarde, Paris 2005, pp. 675-676.

37. Reese, W. L., Choice of Law in Tort Cases. Chaplin v. Boys (England: Court of Appeal and House of Lords), The American Journal of Comparative Law, 1970, pp.189-194.

38. Reese, W. L., Dépeçage: a common phenomenon in choice oflaw, Columbia Law Review, 1973, pp. 58-75.

39. Rigaux, F.; Fallon, M., Droit international privé, Larcier: Bruxelles, 2005.

40. Sieghörtner, R., Internationaler Mietwagenunfall - Zulassungsort als relevantes Anknüpfungskriterium? Neue Zeitschrift für Verkehrsrecht (NZV), 2003, pp. 105-117.

41. Staudinger, A., Rome II and traffic accidents, The European Legal Forum, 2005, pp. 61-67.

42. Stevenson, C. G., Dépeçage: Embracing Complexity to Solve Choice-of-Law Issues, Indiana Law Review, Vol. 37, 2003, p. 303. 
43. Stone, P., The Rome II Regulation on Choice of Law in Torts, Ankara Law Review, Vol. 4, 2007, pp. 95-130.

44. Symeonides, S., American Choice of Law at the Dawn of the 21st Century. Willamette Law Review, Vol. 37:1, 2001, pp. 11-16.

45. Symeonides, S. C., The American Choice-of-Law Revolution: Past, Present and Future, Brill Nijhoff, 2006.

46. Symeonides, S. C., Rome II and tort Conflicts: A Missed opportunity. The American Journal of Comparative Law, Vol. 56, No. 1, 2008, pp. 173-222.

47. Van Calster, G., European Private International Law, Hart Publishing, 2010.

48. Von Hein, J., Something Old and Something Borrowed, but Nothing New-Rome II and the European Choice-of-Law Evolution, Tulane Law Review, Vol. 82, 2007, p.1663.

49. Von Hein, J., Article 4 and traffic accidents, In: Ahern, J. \& Binchy, W. (eds.), The Rome II Regulation on the law applicable to non-contractual obligations: A New International Litigation Regime, Brill Nijhoff, 2009, pp. 153-173.

50. Von Savigny, F. K., Private International Law (1849). A Treatise on the Conflict of Laws and the Limits of Their Operation in Respect of Place and Time, Translation by William Guthrie, Edinburgh, T. \& T. Clark, 1869.

51. Vyshka, K., Changing balances of PIL theories in a Europeanized Private International Law, Maastricht Journal of European and Comparative Law, Vol. 25, No. 5, 2018, pp. 533-550.

52. Wasserer, S., Paradigmenwechsel in der internationalen Zuständigkeit für Direktklagen: Wohnsitzgerichtsstand des Geschädigten bei Klagen gegen ausländische Kfz-Haftpflichtversicherungen, European Law Reporter, 2008, p.143-147.

53. Weintraub, R., Discretion versus Strict Rules in the field of Cross-Border Torts, 2005, Available at: https://dianawallis.org.uk/cy/document/seminar-14-march/weintraub-discretion-vs-strict-rulesin-the-field-of-cross-border-torts\#document. [Last accessed March $11^{\text {th }}, 2020$ ].

54. Wilde, C. L., Dépeçage in the Choice of Tort Law, 41, Southern California Law Review, Vol. 329, 196768, pp. 342-345.

\section{LIST OF COURT DECISIONS (CASE LAWS), ACTS AND REGULATIONS}

1. Case C-148/02 Garcia Avello, EU:C:2003:539.

2. Case C-353/06 Grunkin-Paul, EU:C:2008:559.

3. Case C-106/16 Polbud, EU:C:2017:804.

4. Case C463/06 Odenbreit, ECLI:EU:C:2007:792.

5. Case C-364/93 Antonio Marinari v Lloyds Bank et al, [1995] ECR I-2719.

6. Case 21/76 Bier v Mines de Potasse d'Alsace [1976] ECR 1735.

7. Case (2001) 1 WLR 1003 (Queen's Bench).

8. Case C-368/16 Assnes Havn v. Navigatos Management (UK) limited, ECLI:EU:C:2017:546.

9. Case C-112/03 Société financière et industrielle du Peloux, ECLI: EU: C:2005:280.

10. Case C-34/09 Ruiz Zambrano, EU:C:2011:124.

11. Case Cour de cassation, chambre civile Audience publique du mardi 19 Avril 1988 in France and Austrian Supreme Court (OGH) 26 January 1995, (1995) in Austria. 
12. Case Boys v Chaplin [1971] AC 356.

13. Case C-159/02 Turner v Grovit ECLI:EU:C: 2004:228.

14. Case C-463/06 FBTO Schadeverzekeringen NV v Jack Odenbreit [2007] ECR I-11321

15. C-347/08 Vorarlberger Gebietskrankenkasse v WGV-Schwäbische Allgemeine Versicherungs AG.

16. Case C-111/09, Ceská podnikatelská pojištovna as, Vienna Insurance Group v. Michal Bilas, Judgment of the European Court of Justice (Fourth Chamber) of 20 May 2010.

17. Case C-521/14 SOVAG - Schwarzmeer und Ostsee Versicherungs-Aktiengesellschaft v If Vahinkovakuutusyhtiö $\mathrm{Oy}$.

18. CJEU, C-340/16, Landeskrankenanstalten-Betriebsgesellschaft - KABEG v. Mutuelles du Mans assurances - MMA, ECtHR, IARD SA.

19. Joined Cases C-359/14 and C-475/14, "ERGO Insurance" SE v "If P\&C Insurance" AS and "Gjensidige Baltic" AAS v "PZU Lietuva" UAB DK.

20. Case C- 240/14, Eleonore Prüller-Frey v Norbert Brodnig and Axa Versicherung AG.

21. American Law Institute's First Restatement of Conflict of Laws in 1934.

22. Amending Council Directives 73/239/EEC and 88/357/EEC (Fourth motor insurance Directive) OJ L 181, 20. 7. 2000, p. 65-74.

23. Article 5 of Council Regulation (EC) 44/2001/EC on Jurisdiction and the Recognition and Enforcement of Judgments in Civil and Commercial Matters, (2001) OJ L/12/1.

24. Article 40(1) of the German EGBGB (Einführungsgesetz zum Bürgerlichen Gesetzbuch).

25. Explanatory Memorandum for the Commission's draft for a Rome II Regulation of 2003, Brussels, 22. 7. 2003 COM (2003) 427 final 2003/0168 (COD).

26. Council Directives 72/166/EEC [1972] OJ L103\84/5/EEC [1984] OJ L8/17) 90/232/EEC [1990] OJ L129/33; 2000/26/EC [2000] OJ L181/65 and 2005/14/EC [2005] OJ L149/14, consolidated in Directive 2009/103/EC [2009] OJ L263/11.

27. Convention on the law applicable to traffic accidents; Concluded at The Hague on 4 May 1971.

28. Council Regulation (EC) 44/2001/EC on Jurisdiction and the Recognition and Enforcement of Judgments in Civil and Commercial Matters, (2001) OJ L/12/1.

29. Convention on the law applicable to traffic accidents; Concluded at The Hague on 4 May 1971.

30. Convention of 2 October 1973 on the Law Applicable to Products Liability.

31. Convention on the law applicable to traffic accidents; Concluded at The Hague on 4 May 1971.

32. Directive 2000/26/EC of the European Parliament and of the Council of 16 May 2000 on the approximation of the laws of the Member States relating to insurance against civil liability in respect of the use of motor vehicles and amending Council Directives 73/239/EEC and 88/357/EEC (Fourth motor insurance Directive).

33. The Hague Convention on product liability, Convention of 2 October 1973 on the Law Applicable to Products Liability.

34. Hague Conference on Private International Law, Overview of The Hague Convention of 4 May 1971 on the Law Applicable to Traffic Accidents (2008).

35. Regulation (EC) No 864/2007 of the European Parliament and of the Council of 11 July 2007 on the law applicable to non-contractual obligations (Rome II) OJ L 199, 31. 7. 2007.

36. Report on the proposal for a regulation of the European Parliament and of the Council on the law applicable to non-contractual obligations ("Rome II") (COM (2003)0427 - C5-0338/2003 2003/0168(COD)) Amendment 38. 
37. Regulation (EU) No 1215/2012 of the European Parliament and of the Council of 12 December 2012 on jurisdiction and the recognition and enforcement of judgments in civil and commercial matters (recast) (Brussels Ia) OJ L 351/1, 20. 12. 2012.

38. Position of the European Parliament adopted at first reading on 6 July 2005 with a view to the adoption of Regulation (EC) No .../2005 of the European Parliament and of the Council on the law applicable to non-contractual obligations ("ROME II").

39. Proposal for a Regulation of the European Parliament and the Council on the Law Applicable to Non-Contractual Obligations (“Rome II") 22.7.2003 COM (2003) 427 final, 2003/0168. 


\section{IZRAVNE TUŽBE PROTIV OSIGURAVATELJA U PREKOGRANIČNIM PROMETNIM NEZGODAMA U EUROPEIZIRANOM MEĐUNARODNOM PRIVATNOM PRAVU - KAKVU ZAŠTITU UŽIVAJU OŠTEĆENE STRANKE?}

\section{Sažetak}

U članku se raspravlja o zakonu koji se primjenjuje na prekogranične prometne nezgode, iz perspektive zaštite oštećenika. Uvođenje načela kao što su izravne tužbe treće oštećene osobe protiv osiguravatelja (forum actoris), uglavnom zbog liberalnog pristupa suda, dovodi u pitanje odnos između međunarodnog privatnog prava Unije i pravila međunarodnog privatnog prava država članica. Ovim se člankom predlaže odgovor na pitanje "Pruža li međunarodno privatno pravo Unije odgovarajuću zaštitu oštećenim strankama?" s ciljem davanja i nekoliko preporuka za reformu Uredbe Rim II.

Ključne riječi: prekogranične prometne nezgode, forum actoris, izravna tužba, mjerodavno pravo, medunarodno privatno pravo Unije

\section{(c) (i) (8)}

This work is licensed under a Creative Commons

Attribution-NonCommercial 4.0 International License.

\footnotetext{
* Klea Vyshka, magistrica prava, Sveučilište Jean Monnet, Département d'études politiques et territoriales, Rue Michelet, 42100 Saint-Etienne, Francuska. E-pošta: klea.vyshka.95@gmail.com. ORCID: https://orcid.org/0000-0002-6229-0950.
} 